\title{
Are public officials really less satisfied than private sector workers? A comparative study in Brazil*
}

\author{
Renata Borges \\ Universidade Federal de Minas Gerais
}

\begin{abstract}
This research aims to compare the public and private sectors with regard to satisfaction at work. We conducted a survey with 670 professionals from both sectors in Brazil. The results of variance analysis confirm previous researches indicating that public officials are less satisfied with their work than private sector workers. However, this result does not repeat when we evaluate the satisfaction dimensions. For instance, public officials reported being more satisfied than private sector workers with regard to social environment and work stability. Unexpectedly, the results suggest that there is no difference between these sectors when we analyze the satisfaction with supervision. Therefore, this article is relevant for Brazilian managers, by offering an empirical research on the distinction between public and private. The article also discusses the theoretical implications, since Brazilian findings do not completely support the international literature.
\end{abstract}

KEYWORDs: public-private comparison; satisfaction at work; public administration.

Os funcionários públicos estão realmente menos satisfeitos que os trabalhadores do setor privado? Um estudo comparado no Brasil

O objetivo desta pesquisa é comparar os setores público e privado em relação à satisfação no trabalho. Foi realizado um survey com 670 profissionais de ambos os setores no Brasil. Os resultados da análise de variância confirmam as pesquisas anteriores indicando que os funcionários públicos estão menos satisfeitos com seu trabalho que os trabalhadores do setor privado. No entanto, esse resultado não se repete quando avaliadas as dimensões da satisfação. Por exemplo, os funcionários públicos relataram estar mais satisfeitos que os trabalhadores da iniciativa privada em relação ao ambiente social e à estabilidade no trabalho. Inesperadamente, os resultados sugerem que não existe diferença entre os setores quando analisada a satisfação com a supervisão. Portanto, este artigo é relevante para os gestores brasileiros, pois oferece uma pesquisa empírica sobre a distinção entre público e privado. Este artigo também discute as implicações teóricas, pois os achados brasileiros não confirmam totalmente a literatura internacional.

Palavras-chave: comparação público-privado; satisfação no trabalho; administração pública.

Article submitted on 29 Oct. 2012 and accepted for publication on 26 Aug. 2013.

* This research was supported by Coordenação de Aperfeiçoamento de Pessoal de Nível Superior (Capes)/Fulbright fellowship. 
¿Los funcionarios públicos están realmente menos satisfechos que los trabajadores del sector privado? Un estudio comparativo en Brasil

El objetivo de esta investigación es comparar los sectores público y privado con relación a la satisfacción en el trabajo. Se realizó un survey con 670 profesionales de ambos sectores en Brasil. Los resultados del análisis de varianza confirman las investigaciones anteriores indicando que los funcionarios públicos están menos satisfechos con su trabajo que los trabajadores del sector privado. Sin embargo, ese resultado no se repite cuando se evalúan las dimensiones de la satisfacción. Por ejemplo, los funcionarios públicos reportaron estar más satisfechos que los trabajadores del sector privado con relación al ambiente social y la estabilidad en el trabajo. Inesperadamente, los resultados sugieren que no existe diferencia entre los sectores cuando se analiza la satisfacción con la supervisión. Por lo tanto, este artículo es relevante para los gestores brasileños, pues ofrece una investigación empírica acerca de la distinción entre público y privado. Este artículo también discute las implicaciones teóricas, pues los hallazgos brasileños no confirman totalmente la literatura internacional.

Palabras clave: comparación público-privado; satisfacción en al trabajo; administración pública.

\section{Introduction}

Brazilian public administration had endured so far three major reforms in the public system as an attempt to professionalize and modernize public institutions. In the years of 1937 and 1967, it was possible to identify the shift from the patrimonialist administration to the bureaucratic model, inspired on Weber's perspective. In 1995, other reform was conducted influenced by the British public reform, which was driven by the 'new public management' principles (Matias-Pereira, 2008). The 'new public management' approach asserts that public organizations should import managerial techniques and processes from private sector. "In particular, public managers should seek to emulate the supposedly successful techniques of their private sector counterparts, e.g. management by objectives, total quality management, performance-related pay" (Boyne, 2002:97).

An opposite stream of researchers offer criticism to the exacerbate mimicry from private organizations. Grandy (2009) asserts that one of the criticism against 'new public management' is related to the efficiency association with private administration. Efficiency in public organizations is different from private organizations because the later is embedded in a competitive environment and is concerned in maximizing profit, while the former might sacrifice efficiency in favor to social values. Additional aspects, regarding the difference between public and private organizations, have also been highlighted such as the distinction of goals, structure, motivation, and human resource management (Rainey and Bozeman, 2000).

Given such criticism, why do theorists and practitioners compare public and private organizations? Why, according to Rainey and Bozeman (2000), does the public-private comparison represent a substantial and growing body of empirical evidence in the literature? The answer is that one sector has a lot to learn from another because so far they have been sharing common pathologies like interpersonal work rules, resistance to change, struggles of 
power, isolation of workers and managers, and centralized decision-making (Hartle, 1985). The public-private comparison is also relevant to understand the environment in which the transferability of management techniques occurs. Besides the practical reasons, Perry and Rainey (1988) add that the organizational theory can be improved if it is possible to make overgeneralizations by understanding the differences and similarities between both sectors.

Empirical findings are not conclusive regarding the difference between public and private organizations. Boyne's (2002) evaluation on 34 quantitative studies, suggests that public management is characterized by more bureaucracy, a stronger desire to promote public welfare, and lower organizational commitment. Rainey and Bozeman's (2000) review on two decades of empirical research comparing public and private organizations, draws attention to this a priori assumption - private organizations do better that public ones - may lead to a biased conclusion. In sum, the literature suggests that general assumptions cannot still be made in the public and private comparison.

Both sides present important remarks. An indiscriminate imitation of the successful practices of business administration may not necessarily lead to good results in the public sector. Indeed, more empirical research is needed to support the decision making of public administrators. Rainey and Bozeman (2000:462) assert that "in governmental policy making about public personnel administration, a priori assumptions once again seem to have defeated accumulated evidence", even though some empirical findings might suggest equal or slightly higher general satisfaction in the public sector. This illustrates that much still has to be done to draw attention of public managers to the public-private distinction.

Therefore, the objective of this research is to investigate the differences of work satisfaction between the public and private organizations. In this sense, this study attempts to explore if the dimensions of work satisfaction are different for public and private organizations. By answering the research question, it is also possible to address additional issues such as contrasting the Brazilian results on public-private comparison regarding work satisfaction with the U.S. research findings and the international literature on the subject.

This study seeks to contribute to the public-private distinction literature by overcoming some limitations of previous research as pointed out by Boyne (2002) and Rainey and Bozeman (2000). The authors argue that response bias, low response rates, selection effects, weak internal validity, and social desirability responses reduce previous findings' representativeness. In contributing to the literature, this study overcomes the temporal bias by analyzing recently collected data, addresses the response bias by including in the sample employees from all hierarchical levels, and assesses the industry limitation by adding data from four different industries.

Regarding the Brazilian literature, this study has much to offer because it provides an empirical comprehension of the public administration state reforms' outcomes, adds to the literature about the public-private distinction, and contributes to promote diversity in the public administration research field. To the practitioners, this study intends to support public managers' decision-making with empirical data. Public managers also need to have available research results to learn from private sector with caution by being aware of the differences 
between public and private employees' needs and perceptions of organizational environment and job related characteristics.

\section{Literature review}

Regardless ownership, funding, or control type, organizational change has been a reality that organizations have to face to pursue 'efficiency' (despite the possible difference in public and private sectors). The changes might be motivated by the necessity to improve service quality delivered to the population and to increase the level of professionalization in public organizations; or by the increase of competitiveness, introduction of new technologies, and variations in the preferences of consumers or partners in private companies. Currently, these changes lead to the adoption or development of new managerial practices which appeals to employees' motivation and involvement as an important factor of success because in some ways employees have to change their behavior to deal with new demands. In fact, Beck and partners (2008) posit that one most common obstacle of implementing changes is resistance, which is often related to the low level of work satisfaction.

Human resource is the basic potential of any company, industry or service, public or private, big or small. Having a committed and satisfied workforce facilitates changes, contributes to high productivity (Hauskennecht et al., 2008; Lee et al., 2008), improves service quality and performance (Zhou et al., 2008), brings flexibility, and enrich organizational climate (Hackman and Oldham, 1980). Creativity and innovation has never been so important for firm's survival (Cabrera, Collins and Salgado, 2006). Zhou and partners (2008) found that employees' satisfaction partially mediated the impact of market orientations behavior on product quality, and employees' satisfaction fully mediates the effect of market orientation behavior on organizational performance. They conclude that satisfied employees help organizations to translate market orientation activities into superior products and performance.

Work satisfaction has also been identified as an important factor that influences absenteeism and turnover. Job satisfaction plays a considerable role on individual's decisions to quit their jobs (Chen et al., 2011; Proenca, 2012). High rates of absenteeism and turnover result in serious problems to organizations because it raises costs and frequently, leads to productivity losses (Hausknecht et al., 2008). The cost of losing employees might be particularly high when it also involves the loss of tacit knowledge (Droege and Hoobler, 2003). Lee and partners (2008) investigate the job satisfaction effect on employees' turnover. The authors estimates how job satisfaction affects turnover in different turnover groups: those quitting after successfully searching for other jobs, those quitting to search for other job, those living in response to unsolicited job offers, and those leaving due to family reasons. The results indicate that job satisfaction is a strong predictor for the first two groups, and a weak predictor for the third group. Accordingly, Yücel (2012) found that high levels of job satisfaction results in lower turnover intention and higher commitment in a sample of 250 Turkish employees. 
Edmans (2012) evaluated the links between work satisfaction and firm value instead of focusing on the link between work satisfaction and individual job performance. After analyzing the 100 best companies to work in America, the author concluded that, consistent with organizational behavior literature, work satisfaction is beneficial for firm value since it is directly related to the financial outcomes of the organization.

In the organizational behavior literature, work satisfaction has been defined as "result from the perception that one's job fulfills or allows the fulfillment of one's important job values" (Locke, 1976:1307). Thus, identifying the job values and how employees perceive it has been satisfied is crucial to work satisfaction research.

Walton (1973), for example, identifies eight factors: fair reward, safe work conditions, the use of skills, possibility of growth, inter-relationship in work, equity, social significance of the work, and reduction of the work-family conflict. Westley (1979) states four major problems that should be solved in order to promote work satisfaction: the sense of economic injustice should be reduced by sharing profit and sealing productivity deals; the feeling of political instability should be reduced by creating worker advisory boards; the psychological alienation should be reduced by enriching the task; and, finally, the sociological anomy should be reduced by creating structured work groups. Hackman and Oldham (1980) developed the job diagnostic survey to measure the causes of work satisfaction. The authors' basic idea is that promoting task enrichment will increase the level of work satisfaction. Werther and Davis (1983) argue that satisfactory and productive positions are essential for job satisfaction. They propose that redesigning positions must account for organizational and behavioral needs. Lastly, Huse and Cummings (1985) focus on the employees' involvement in the decision-making.

In sum, studies on work satisfaction usually highlight how organizational characteristics and job-related conditions influence the perception of work satisfaction. According to Glisson and Durick (1988), empirical findings have supported the assumption that employees' satisfaction at work are intrinsically related to aspects of the task itself such as the amount of complex and different abilities employees use to perform their daily activity and the job overall importance to the organization, co-workers, and society.

The context in which employees are embedded also influence individuals' perceptions related to the fulfillment of important job values. In this sense, organizational context plays a major role as source of satisfaction or dissatisfaction in the workplace. Public and private sectors have their own specificities since private organizations are embedded in a competitive environment which the main concern is maximizing profit whereas public organizations might consider sacrificing efficiency in favor of social welfare (Grandy, 2009).

\subsection{Work satisfaction on public and private sectors}

Work satisfaction has also been researched in the public-private context. DeSantis and Durst (1996) found that monetary reward and personal characteristics such as educational level 
are strongly related to job satisfaction in private employees while job significance and organizational climate is stronger for public employees. Buelens and Broeck (2007) draw attention to interesting aspects of job satisfaction. They conducted an empirical research with 3723 employees from both sectors in Belgium. The findings suggest that public employees have higher levels of work satisfaction because they experience less work-family conflict, they have fewer working hours, present less willingness to exert considerable effort on the behalf of the organization, and are less motivated by extrinsic rewards when compared to private sector employees.

It illustrates how the literature on work satisfaction comparing public and private organizations does not converge toward the a priori assumption that private employees are more satisfied with their jobs than public employees (Rainey and Bozeman, 2000). In fact, the lack of convergence might be related to the multidimensionality of the work satisfaction concept, which leads to a great variety of measurement instrument available in the literature. However, such variety may not be an issue when broad similarities about what workers expect from their jobs are identified (Henne and Locke, 1985). In general, people want to be paid with fairness (competitive benefits, be able to meet their own expenses, and equality related to positions); employees want to have the possibility of growth in their careers through a fair and transparent system; workers want to be treated with respect by a competent supervisor who recognizes, rewards, and allows some degree of participation in decision-making processes; people want to work in a pleasant and safe work environment; and, finally, workers want to work without the constant threat of losing their jobs.

In this sense, the results reveal that whether or not public employees are more satisfied than private ones depends on the question researchers are trying to answer. It means that, if work satisfaction has been assessed as a result of work-family conflict, stress level, and organizational environment, for example, public employees will report higher levels of work satisfaction than private employees. If work satisfaction has been assessed as a result of reward, career development, and autonomy, private employees will report higher levels of work satisfaction than public workers (Buelens and Broeck, 2007).

Rainey (1983) investigated 40 middle managers of public and private organizations in the U.S. The findings confirm that public managers are less satisfied than private managers when they perceive that their own performance is weakly related to monetary incentives. On assessing data from the National Longitudinal Surveys of Youth (NLSY), DeSantis and Durst (1996) show that public employees report higher work satisfaction than private employees regarding organizational climate and quality of supervision. Karl and Sutton (1998) compared 170 public organizations with 47 private firms in the U.S. The results indicate that private sector workers value good wages the most, while public sector workers place higher value on significant and interesting work.

The quality of supervision and degree of bureaucracy were also found to influence the level of work satisfaction in both sectors. In the private sector, Finlay and partners (1995) report that even when job ambiguity, job variety, and job autonomy were included, the existence of a low degree of standardized procedures and a high degree of communication across 
the organization was found to have significant positive effects on work satisfaction. In the U.S. public sector, effective supervisory communication allied with a participative management style was found to positively influence the levels of work satisfaction (Kim, 2005). In a publicprivate comparison, Rainey (1983) supports the propositions that public managers will show lower scores in work satisfaction because they perceive high levels of formalization.

Regarding the overall concept of work satisfaction private employees will tend to report higher levels of work satisfaction than public workers. Although there is an attempt to professionalize public administration supported by the New Public Management principles, the public sector still faces traditional problems as result of red tape, for example the lack of autonomy, reduced capacity to reward employees, and failure to promote them without political influence. Thus, based on the international literature findings, the following hypothesis is proposed:

H1. Private employees are more likely to report higher levels of work satisfaction than public employees.

Work satisfaction is a broad concept that does not add much about the reason why employees are satisfied. Analyzing the aspects of work satisfaction, such as satisfaction with compensation, possibility of growth, quality of supervision, organizational environment, and job security, as proposed by Walton (1973) and Hackman and Oldham (1980), allow a better understanding of the phenomena. Hence, it is possible to indentify specifically in what features employees are satisfied or dissatisfied by adopting this perspective.

In a qualitative research, Annakis and partners (2011) found that work satisfaction is related to the quality of supervision and organizational environment in Australian private organizations. In accordance, DeTienne and partners (2012) add that the environment plays a critical role on work satisfaction. The survey results indicate that organizations significantly reduce the level of work satisfaction by allowing moral stress to develop. The investigation of Ferguson and Cheek (2011) draw attention to the influence of supervision on work satisfaction. Their findings suggest that employees' satisfaction is substantially affected by their supervisor because workers are more satisfied with their jobs if they perceive their job related efforts are not constrained by their supervisor.

Comparing public and private sectors, the research of Wang and partners (2012) implies that public employees are more satisfied that private workers in relation to job security because the ultimate reason individuals search for public jobs are their greater need for security. Public employees also look for a less competitive and more supportive environment in the workplace. On the other hand, private employees reported higher levels of satisfaction with reward and possibility of growth, explained by the level of salary pay, flexibility in work process, and autonomy, which are higher than the public sector.

Based on the international literature on the public-private distinction, we can expect different perceptions related to work satisfaction. Previous research findings indicate that public employees still value aspects that motivated them to look for public jobs in the first place, such as job security and social environment (Perry and Wise, 1990). On the contrary, private 
employees value aspects of the job related to financial incentives and the real possibility to reach higher positions in the organizational hierarchy.

In relation to supervision, although the international literature suggests that private employees will be more satisfied due to the lack of political influences, it is important to address that Brazilian environment might influence such reasoning. In Brazil, the boundaries between work and personal spheres are not as high as in the U.S., for example. It means that Brazilian employees frequently develop friendships in the workplace mixing personal and professional relationships. This phenomenon exists to a greater degree in public administration due to job security and patrimonialist aspects (Motta, 1996). Following this reasoning, managers in public sector tend to be less effective than their counterparts in the private sector because they also have to take into account personal relations in the workplace when making a decision. Moreover, public managers face severe constraints regarding personnel management which reduces their ability to minimize the influence of personal relationships. Thus, since public managers to not exert their authority as private managers do, public employees will tend to be more satisfied with supervision than private workers.

Therefore, regarding the five dimension of work satisfaction, the following hypotheses are posed comparing both sectors:

H2. Private employees are more likely to report higher levels of satisfaction with compensations than public employees.

H3. Private employees are more likely to report higher levels of satisfaction with the possibility of growth than public employees.

H4. Public employees are more likely to report higher levels of satisfaction with job security than private employees.

H5. Public employees are more likely to report higher levels of satisfaction with supervision than private employees.

H6. Public employees are more likely to report higher levels of satisfaction with social environment than private employees.

\section{Methodology}

In order to answer the research question and to test the hypotheses, we conducted a survey research. Individuals who are employed in public and private organizations are the unit of analysis of this research. According to Babbie (2007), for social researchers who are interested in collecting original data for describing a population too large to observe directly, survey research is probably the best method available. Fowler (2008) adds that one of the objectives of survey methodology is to minimize the random differences between the sample and the population. 


\subsection{Population and sample}

This study assess employees from the Minas Gerais State Secretaries of Education, Health, and Administration and Planning, which occupy the first, third, and fifth positions respectively in the rank of working employees' expenses. The State Secretary of Education is responsible for formulating and coordinating the Minas Gerais state educational policies and for supervising policy implementation in institutions that are under the state competency. The mission of the State Secretary of Health is to formulate, regulate, and foment the health policies of Minas Gerais state according to the population needs; and also assure the functioning of the Health Unique System The aim of the State Secretary of Planning and Administration is to integrate governmental actions through coordination and planning, to support the Minas Gerais state development, and to improve the quality of life of Minas Gerais citizens.

The private sector is represented in this study by the two largest mining organizations of Brazil (Valor Econômico, 2010). The mining sector has contributed to 70 billion dollars per year, representing 5\% of Brazilian's GDP while the industrial sector in Brazil represents $28 \%$ of the GDP, according to the Brazilian Institute of Geography and Statistics (IBGE, 2012). How these represent Brazilian private organizations is assessed by Rodrigues (2002) who investigated one of the organizations in the mining industry comparing the cultural traits existent in the Brazilian society with those identified in the organizational culture. The results indicate that the culture of mining multinational organizations in Brazil is consistent with the cultural patterns of Brazilian organizations in general, as described by Javidan and partners (2006). In the Brazilian private organizations the deadlines are strictly observed, the formality is respected as well as the hierarchy, and the view is focused on the long term.

In the State Secretaries of Education, Health, and Planning and Administration, the amount of employees who participated of this study are 347,326 , and 252, respectively. In the private organizations researched, 339 employees participated in this study. Before running the analysis, we assessed the variance between and within the public and private samples. The results show, as expected, homogeneity within the three secretaries and the two private organizations, followed by heterogeneity between the two groups - public and private employees. Therefore, indicating that the sample is suitable for its purpose.

As a result of power analysis, at least 243 cases are needed to detect, at .05 significance level, a medium population effect of .15 (the strength of the relationship between two variables in a statistical population of .15 will be detected) with $95 \%$ of probability. At any given $\alpha$ level, increased sample sizes always produce greater power of the statistical test. In a post hoc power analysis utilizing the $G^{*}$ Power software, the results indicate a power of .996 for the sample size of 339 (because it is the smallest sample). The effect size and the significance level were also computed to evaluate the impact of the sample size obtained and the new power level achieved. The results indicate that the values set previously remained unchanged.

Therefore, the sample size of 339 for the private sector is adequate for this study. For the public sector, the sample will be randomly reduced to keep the parity to the private sector for two reasons. The first is that comparing groups with unequal sample sizes influences the 
analysis and requires additional interpretation of the results. The second reason is that, according to Hair and partners (2010), sample sizes greater than 400 respondents lead to overly sensitive statistical tests, demanding the researcher to examine all significant results to ensure they have practical significance.

\subsection{Instrument design and development}

The standardized questionnaires administered are comprised of two sections. The first section assesses the individual characteristics, which are the demographic questions with no identification of the respondent, just identifying the firm's membership. The second section measures the construct work satisfaction. The questionnaire is composed by a combination of the Job Diagnostic Survey instrument developed by Hackman and Oldham (1980) and the eight factors identified by Walton (1973). Five variables capture contextual work satisfaction, which are defined as:

a. Satisfaction with job security is the amount of threat an employee has to lose his/her job.

b. Satisfaction with rewards and benefits is the amount of pay and benefits the employee receives.

c. Satisfaction with organizational environment is the amount of satisfaction with the organizational climate.

d. Satisfaction with supervision is the degree of quality, respect, and fair treatment that the supervisor treats the employee.

e. Satisfaction with the possibility of growth is the likelihood to get a better position in the organization.

The measurement of each variable consists of at least three items that were assessed using a five point Likert type scale varying from 1 for extremely dissatisfied to 5 for extremely satisfied. To illustrate, the questions are: the amount of pay I receive, the amount of fringe benefits I receive, and the degree to which I am fairly paid for what I contribute to this organization, for satisfaction with reward; and the degree of respect and fair treatment I receive from my boss, the amount of support and guidance I receive from my supervisor, and the overall quality of the supervision I receive in my work, for satisfaction with supervision.

According to the measurement model, the overall concept of work satisfaction is a combination of each of its dimensions (Hackman and Oldham, 1980). Thus, work satisfaction accounts for satisfaction with security, rewards and benefits, possibility of growth, organizational environment, and supervision. The measure of work satisfaction is, therefore, composed by an average of the five dimensions. In this sense, it is possible to identify the most influential variables that compose the construct work satisfaction by assessing the measurement model validity.

The administration of the questionnaire followed the same procedures for all organizations. The managers of each department were informed about the research objectives and 
invited to meet the researcher at the organization's auditorium in a previously scheduled time. They were also asked to extend the invitation to their subordinates. Hence, this is a convenience sample, in which individuals were selected due to their accessibility. As soon as the employees arrived in the organization's auditorium, they were informed about all aspects of the research project, that there was no need for individual identification, and the voluntary characteristic of the participation. In addition, in the first page of the paper-based questionnaire, a letter reinforced the objectives of the research, the voluntary participation, anonymity, and confidentiality of the information. In fact, no direct identification of individual subjects was possible because no personal information such as name, date of birth, or social security number, was recorded.

Because social research usually deals with subjective constructs which by nature might accounts for bias, the common method variance is usually mentioned. Common method variance is a systematic variance introduced into the measure as result of the measurement technique utilized. Usually, self-reports questionnaires (because self-report measures are supposed to be correlated), social desirability (it might inflate observed correlations), negative affectivity (respondent's negative emotions might bias the relationships in a negative direction), and acquiescence (the tendency to agree with the items no matter the content) are cited as most usual sources of common method variance. As result, several statistical procedures were developed to overcome this problem, such as the traditional MTMM matrix procedure, the CFA-based MTMM technique, Harman's single-factor test, and marker-variable technique (Malhotra, Kim and Patil, 2006).

Common method bias, resulting from common method variance, represents the degree of the discrepancies between the observed and the true relationships between constructs (Doty and Glick, 1998). In fact, some authors believe that it is an urban legend that everything measured with the same method shares common method variance, because the presence of common method variance does not necessarily lead to common method bias (Doty and Glick, 1998; Malhotra, 2004; Spector, 2006). Spector (2006) points out that the multi-method correlations were not consistently found smaller that the mono-method correlations and suggests that instead of focusing the attention on the method employed, the researcher should consider looking for alternative solutions depending on the nature of the construct of interest.

Although self-reported questionnaires are vulnerable to common method variance, the researcher can employ some strategies to minimize its effects, such as assuring the respondents anonymity and confidentiality, using different scales and inverted items to assess the construct, sensitizing the respondent to answer the questions honestly, counterbalancing the order of the questions, and utilizing well established instruments available in the literature. All these strategies were employed in this research.

\subsection{Analysis strategy}

Broadly, the data analysis consisted of employing data reduction technique (confirmatory factor analysis) to assess the reliability and validity of the measurement instrument. Since we utilized well known and extensively tested instruments available in the literature, there 
is no need to run an exploratory factor analysis (Creswell, 2010). To test the hypotheses, an analysis of variance (ANOVA) was conducted to assess the group differences. But, first, we detected and handled outliers, searched for missing data patterns, and tested for normality and homoscedasticity assumptions. The SPSS software was used to run data preparation analysis and analysis of variance. The confirmatory factor analysis was run on EQS software to test the measurement model since work satisfaction is a latent variable.

\section{Findings}

As specified in the power analysis, we reduced the number of respondents from the public sector to maintain the parity to private sector by selecting randomly $42 \%$ of public sector cases. We also checked whether the proportion of each organization was kept. See Table 1 for the sample demographic characteristics in each sector.

\section{Table 1}

\section{Demographic data}

\begin{tabular}{|c|c|c|c|c|c|c|c|}
\hline & & Private & Public & & & Private & Public \\
\hline \multirow[t]{3}{*}{ Gender } & Male & 282 & 100 & \multirow[t]{3}{*}{ Parenthood } & Have children & 209 & 111 \\
\hline & Female & 36 & 244 & & Do not have children & 103 & 123 \\
\hline & No response & 3 & 5 & & No response & 9 & 80 \\
\hline \multirow[t]{7}{*}{ Age } & less than 25 yrs old & 52 & 17 & \multirow[t]{7}{*}{ Tenure } & Less than $1 \mathrm{yr}$ & 46 & 94 \\
\hline & from 26 to 30 yrs & 41 & 19 & & from 1 to $5 \mathrm{yrs}$ & 56 & 115 \\
\hline & from 31 to 35 yrs & 49 & 23 & & from 6 to $10 \mathrm{yrs}$ & 51 & 1 \\
\hline & from 36 to 40 yrs & 64 & 30 & & from 11 to $15 \mathrm{yrs}$ & 58 & 12 \\
\hline & from 41 to 45 yrs & 53 & 61 & & from 16 to 20 yrs & 56 & 52 \\
\hline & more than 45 yrs old & 61 & 196 & & more than 20 yrs & 50 & 30 \\
\hline & No response & 1 & 3 & & No response & 4 & 39 \\
\hline Marital & Single & 88 & 93 & \multirow[t]{5}{*}{ Position } & Manager / Supervisor & 8 & 64 \\
\hline \multirow[t]{4}{*}{ status } & Married & 211 & 185 & & Engineer / Analyst & 50 & 146 \\
\hline & Divorced & 16 & 37 & & Operational technician & 53 & 173 \\
\hline & Widow & 2 & 18 & & No response & 1 & 102 \\
\hline & No response & 4 & 16 & & & & \\
\hline Educational & Basic education & 5 & 14 & Salary & Less than $11,000.00$ & 42 & 30 \\
\hline \multirow[t]{5}{*}{ level } & Elementary school & 50 & 26 & (dollars & from $11,000.00$ to $25,999.00$ & 44 & 17 \\
\hline & High school & 205 & 99 & \multirow[t]{4}{*}{ per year) } & from $26,000.00$ to $36,990.00$ & 12 & 9 \\
\hline & Graduate & 35 & 94 & & from $37,000.00$ to $73,990.00$ & 4 & 111 \\
\hline & Posgraduate & 24 & 115 & & More than $74,000.00$ & 7 & 123 \\
\hline & No response & 2 & 1 & & No response & 3 & 80 \\
\hline
\end{tabular}

Source: Research data. 
To access the instrument/model reliability and validity, Hair and partners (2010) point out that multiple fit indices should be reported to indicate a good measurement model, such as chi-square statistics $\left(X^{2}\right)$, at least one absolute fit index, one incremental fit index, one goodness-of-fit index, and one badness-of-fit index. The chi-square value and the associated degrees of freedom, which is the difference between the observed and estimated covariance matrices, is expected to be significant due to the overall sample size. The root mean square error of approximation (RMSEA) is acceptable below .10, and the cutoff value for the comparative fit index (CFI) and the goodness-of fit index (GFI) is .90. Poor fit indices, low standardized factor loadings, and high errors provide evidence of the lack of unidimensionality.

Assessing the measurement model convergent validity also includes analyzing the path estimates, standardized residuals, and modification indices. Hair and partners (2010) argue that standardized path estimates with absolute values lower than .50 are candidates for deletion, which standardized residuals with absolute values greater than 4.0 suggest potential error, and that modification indices can be used only as guide to model improvements since researchers must rely on theory in the first place. As result of the confirmatory factor analysis, the work satisfaction measurement model $\left[X^{2}(75)=692.56, p<.01\right]$ returned GFI $(.98)$ and CFI (.91) values greater than .90 and RMSEA (.09) indices below .10. No standardized residuals exceeded the \pm 4.0 threshold and all standardized factor loadings scored significantly above .50 .

For the work satisfaction variables the average variance extracted (AVE) and reliability measures exceeded the threshold values. Since all standardized factor loadings are greater than .50, the AVE of the latent variables are greater than 50\%, and, finally, the Cronbach's alpha reliability measure exceeds the .70 value, we conclude that the measurement model indicates good convergent validity for all latent variables. Table 2 displays the factor loadings, average variance extracted (AVE), and reliability (Cronbach's alpha) values for the measurement model.

Table 2

Measurement model reliability and validity

\begin{tabular}{|clccc|}
\hline Construct & \multicolumn{1}{c}{ Variables } & Standardized loadings & AVE & Reliability \\
\hline Work satisfaction & Security & 0.695 & 0.513 & 0.708 \\
& Compensation & 0.793 & & \\
& Possibility of Growth & 0.940 & & \\
& Supervision & 0.556 & & \\
& Organizational Environment & 0.509 & & \\
\hline
\end{tabular}

Source: Research data.

Note: All the standardized loadings are significant at $p<.05$.

The measurement model indicates how well the five variables (security, compensation, possibility of growth, supervision, and organizational environment) represent the work satis- 
faction construct. The findings indicate that among the five dimensions, possibility of growth is strongly associated with work satisfaction, followed by compensation (rewards and benefits). Satisfaction with job security is the third most influential variable. Lastly, satisfaction with supervision and organizational environment were also found to influence the level of work satisfaction.

\subsection{Testing the hypothesis}

To assess the differences between the public and private sectors, we run the ANOVA test. We run Levene's test to determine whether the variance of public and private sectors across all variables are equal. Homoscedasticity assumes equal variances throughout the dataset. The results indicate the heterogeneity of variances across all the variables based on mean differences. Thus, the results of Welch test were reported due to their consistency when variances are unequal and also for many non-normal distributions (Zimmerman, 1998). Table 3 summarizes the research findings of the analysis of variance.

Table 3

Research findings

\begin{tabular}{|c|c|c|c|c|c|c|}
\hline & \multirow{2}{*}{ Variables } & \multicolumn{2}{|c|}{ Private } & \multicolumn{2}{|c|}{ Public } & \multirow{2}{*}{$\mathrm{F}$ value } \\
\hline & & Mean & s.d. & Mean & s.d. & \\
\hline $\mathrm{H} 1$ & Overall Work Satisfaction & 3,85 & 0,50 & 3,36 & 0,79 & $90.17 *$ \\
\hline $\mathrm{H} 2$ & WS_Compensation & 3,42 & 0,85 & 2,49 & 1,19 & $134.58^{*}$ \\
\hline H3 & WS_Possibility Growth & 3,98 & 0,52 & 2,69 & 1,12 & $361.78^{*}$ \\
\hline $\mathrm{H} 4$ & WS_Job security & 4,05 & 0,87 & 4,35 & 1,17 & $14.79 *$ \\
\hline H5 & WS_Supervision & 3,86 & 0,69 & 3,97 & 1,09 & 2,32 \\
\hline H6 & WS_Social Environment & 4,15 & 0,54 & 4,35 & 0,71 & $15.94 *$ \\
\hline
\end{tabular}

Source: Research data.

$\mathrm{n}=670, * \mathrm{p}<.01$.

Overall satisfaction, which is the work satisfaction construct, is significantly different for the public and private sectors $[F(1,528.49)=90.17, p<.001]$. Private employees reported significantly higher levels of overall satisfaction when compared to public employees, supporting Hypothesis 1. Regarding the elements of overall satisfaction, four of the five components resulted in significant differences between sectors. Satisfaction with compensation is significantly different for public and private employees $[F(1,606.94)=134.58, p<.001]$. This means that private employees reported significantly higher levels of satisfaction with compensation than public employees, thereby supporting Hypothesis 2 .

The results indicate that satisfaction with the possibility of growth is significantly different between the two sectors $[F(1,476.25)=361.78, p<.001]$. Hypothesis 3 is supported be- 
cause private employees reported significantly higher levels of satisfaction with the possibility of growth than public employees. Satisfaction with job security is significantly different for the public and private sectors $[F(1,630.89)=14.79, p<.001]$. As predicted, public employees reported significantly higher levels of satisfaction with job security than private employees, supporting Hypothesis 4.

Although public employees reported higher levels of satisfaction with supervision, the ANOVA results indicate that there is not a significant difference between the two sectors $[F(1,574.99)=2.32, p=.129]$, failing to support Hypothesis 5. Satisfaction with the social environment was found to be significantly different between the two groups $[F(1,631.14)=$ $15.94, p<.001]$. Thus, Hypothesis 6 is supported, indicating that public employees are significantly more satisfied with the social environment than private employees.

\section{Conclusions}

This research sought to determine how work satisfaction varies across public and private sectors. To answer the research question, we proposed six hypotheses, mostly consistent with the international literature, although the data was collected in Brazil. By supporting or failing to support the posed hypotheses, we can compare American's and Brazilian's research findings as well as international findings on public-private comparison.

\subsection{Theoretical contributions}

This study's main contribution is adding to the public-private comparison literature by including non-American data and overcoming the problems of temporal bias, lack of diversity, and respondent bias (Boyne, 2002). This study has expanded the Brazilian literature significantly by providing results based on data from Brazilian public and private sectors and by accounting for cultural specificities. By doing so, this research also offers an initial comparison between Brazilian and American public-private sectors distinction.

The overall level of work satisfaction is significantly higher for private employees than for public employees, which supports American studies. Henne and Locke (1985) assert that in general, regardless ownership, people want to work in a consistent, fair, and safe environment. However, due to formalization and bureaucracy issues, the public sector has less success in meeting employees' expectations, leading to lower levels of work satisfaction when compared to private employees' satisfaction (Rainey, 1983; DeSantis and Durst, 1996; Buelens and Broeck, 2007).

In relation to specific aspects of work satisfaction, Rainey and Bozeman (2000) conclude that depending on the research question, public employees will report different levels of work satisfaction. Our results confirm this assumption by revealing that public employees are more satisfied than private employees in some aspects, but less satisfied in other aspects. For 
example, questions related to job security and social environment, public employees display higher levels of work satisfaction than private employees (DeTienne et al., 2012; Wang et al., 2012). However, when the questions are about compensation and the possibility of growth, private employees report significantly higher levels of work satisfaction (see also Rainey, 1983; Buelens and Broeck, 2007; Karl and Sutton, 1998).

In contrast, our findings fail to support international findings on supervision, which assert that private employees are more satisfied with the quality of supervision than public employees (DeSantis and Durst, 1996; Ferguson and Cheek, 2011). Our data suggests that there is not a significant difference on satisfaction with supervision between the public and private sectors in Brazil, drawing attention to an important aspect of Brazilian culture, such as the fine line between professional and personal lives. This finding might be particularly interesting to the leadership research on cross-country effects since it tries to identify patterns of behaviors managers from all around the world should have when dealing with Brazilian employees (Javidan et al., 2006).

\subsection{Managerial implications}

This research offers valuable practical implications for managers and employees in both public and private sectors. First, it supports managers with empirical data, offering a way to enhance employees' work satisfaction. The five dimensions of work satisfaction have been successfully linked as representative of the construct. The measurement model shows that managers might enhance work satisfaction along five aspects. Working on employees' possibility to achieve a better position in the organization (possibility of growth) is the most effective way to improve individual's satisfaction. The second most influential aspect of satisfaction is the compensation dimension (rewards and benefits). Job security is the third concern followed by the quality of supervision. Finally, managers can also increase the level of work satisfaction by working on the social environment climate.

This study also aids public managers in Brazil by offering many conclusions about the public-private distinction. Public managers must understand the different reasons employees feel satisfied, and they must understand how the levels of satisfaction vary between public to private organizations; these understandings are crucial to public managers' decisions to import managerial techniques from the private sector. Our findings suggest that public employees are more satisfied with their job security and social environment than private employees. Thus, managerial practices designed to increase competition and enhance organizational climate should be imported with caution.

The international literature is not supported by our findings regarding the quality of supervision. This study's findings indicate that public employees are neither more nor less satisfied with supervision than private employees. Our best guess is that Brazilian culture plays a major role in the relationship between the leader and his/her team which, in turns, reduces significantly the differences between both sectors. This finding might be an important indicator of the patrimonialist influence of Brazilian culture. As suggested by Motta (1996), 
the private sector in Brazil displays patrimonialist characteristics because interpersonal relationships still influence important decisions about personnel management (at least those that are in managers' hands). Following this reasoning, it is also important for private sector employees in Brazil to maintain good relationships with supervisors since it entails a greater level of interpersonal dynamics.

\subsection{Limitations and future research directions}

As any research, this study also has several limitations. The methodological limitations include the possible representativeness of Brazilian public sector, sample selection, response rate, and common method bias. Another limitation involves the generalizability of the findings; all respondents are from Brazil, thereby limiting the applicability of the results in other countries and research contexts. The last potential limitation of this study is the selection of the variables which represent the concept work satisfaction. Future research could include different variables or could utilize other measurement models, selecting from the many available in the literature.

Future research could also confirm or investigate why there is no difference between both sectors in regards to satisfaction with supervision. We assume that the Brazilian public sector is less negligent on this area than the U.S. public sector, for example, where stability does not exist and competition is enforced. Or that the Brazilian private sector is worse than the U.S. private sector, due to an increase of competition, conflict, and overestimation of interpersonal relationship.

Future research could further the study on the mediation effect of ownership between work satisfaction and its predictors. The effect of ownership's mediation in the relationship between job, organizational, and individual characteristics and work satisfaction might hold across public and private organizations, helping to clarify how work satisfaction phenomenon manifests in Brazil.

Finally, future research could add to the analysis hybrid organizations. Instead of focusing on the public-private distinction, researchers could also improve the comprehension of work satisfaction by investigating how employees of mixed capital companies perceive their work along the five dimensions of satisfaction.

This research seeks to offer a significant contribution, especially to the Brazilian public sector, since public-private comparison is relevant to understand the context in which the transferability of management techniques occurs. It is also important to be aware of the differences between public and private employees' needs and perceptions.

\section{References}

ANNAKIS, John; LOBO, Antonio; PILLAY, Soma. Exploring monitoring, work environment and flexibility as predictors of job satisfaction within Australian call center. International Journal of Business and Management, v. 6, n. 8, p. 75-93, 2011. 
BABBIE, Earl R. The practice of social research. California: Wadsowrth, Cengage Learning, 2007.

BECK, Nikolaus; BRÜDERL, Josef; WOYWODE, Michael. Momentum or decelaration? Theoretical and methodological reflections on the analysis of organizational change. Academy of Management Journal, v. 51, n. 3, p. 412-435, 2008.

BOYNE, George A. Public and private management: what's the difference? Journal of Management Studies, v. 39, n.1, p. 97-122, 2002.

BUELENS, Marc; VAN DEN BROECK, Herman. An analysis of differences in work motivation between public and private organizations. Public Administration Review, v. 67, n. 1, p. 65-74, 2007.

CABRERA, Angel; COLLINS, William C.; SALGADO, Jesús F. Determinants of individual engagement on knowledge sharing. International Journal of Human Resource Management, v. 17, n. 2, p. 245-264, 2006.

CHEN, Gilad et al. The power of momentum: a new model of dynamic relationships between job satisfaction change and turnover intentions. Academy of Management Journal, v. 54, n. 1, p. 159181, 2011.

CRESWELL, John W. Projeto de pesquisa: métodos qualitativo, quantitativo e misto. 3. ed. Porto Alegre: Artmed, 2010.

DESANTIS, Victor S.; DURST, Samantha L. Comparing job satisfaction among public- and privatesector employees. American Review of Public Administration, v. 26, n. 3, p. 327-343, 1996.

DETIENNE, Kristen B. et al. The impact of moral stress compared to other stressors on employee fatigue, job satisfaction, and turnover: an empirical investigation. Journal of Business Ethics, v. 110, n. 3, p. 377-391, 2012.

DOTY, Harold D.; GLICK, William H. Common methods bias: does common methods variance really bias results? Organizational Research Methods, v. 1, n. 4, p. 374-406, 1998.

DROEGE, Scott B.; HOOBLER, Jenny M. Employee turnover and tacit knowledge diffusion a network perspective. Journal of Managerial Issues, v. 15, n. 1, p. 50-64, 2003.

EDMANS, Alex. The link between job satisfaction and firm value, with implications for corporate social responsibility. Academy of Management Perspectives, v. 26, n. 4, p. 1-19, 2012.

FERGUSON, Tamela D.; CHEEK, Ron. How important are situational constraints in understanding job satisfaction?. International Journal of Business \& Social Science, v. 2, n. 22, p. 221-227, 2011.

FINLAY, William et al. Organizational structure and job satisfaction: do bureaucratic organizations produce more satisfied employees? Administration \& Society, v. 27, n. 3, p. 427-450, 1995.

FOWLER JR., Floyd J. Survey research methods. 4. ed. California: Sage, 2008.

GLISSON, Charles; DURICK, Mark. Predictors of job satisfaction and organizational commitment. Administrative Science Quarterly, v. 33, n. 1, p. 61-81, 1988.

GRANDY, Christopher. The "efficient" public administrator: pareto and a well-rouded approach to public administration. Public Administration Review, v. 69, n. 6, p. 1115-1123, 2009. 
HACKMAN, Richard J.; OLDHAM, Greg R. Work redesign. Reading, MA: Addison-Wesley, 1980.

HAIR, Joseph F. et al. Multivariate data analysis. Upper Saddle River, NJ: Prentice Hall, 2010.

HARTLE, Terry W. Sisyphus revisited: running the government like a business. Public Administration Review, v. 45, n. 2, p. 341-351, 1985.

HAUSKNECHT, John P.; HILLER, Nathan J.; VANCE, Robert J. Work-unit absenteism: effects of satisfaction, commitment, labor market conditions, and time. Academy of Management Journal, v. 51, n. 6, p. 1223-1245, 2008.

HENNE, Douglas; LOCKE, Edwin. A. Job dissatisfaction: what are the consequences? International Journal of Psychology, v. 20, n. 2, p. 221-240, 1985.

HUSE, Edgar F.; CUMMINGS, Thomas G. Organization development and change. Saint Paul: West Publishing, 1985.

IBGE. Instituto Brasileiro de Geografia e Estatística. 2012, March 10. Available at: <www.ibge.gov. br>. Retrieved on: 10 mar. 2012.

JAVIDAN, Masour et al. In the eye of the beholder: cross cultural lessons in leadership form project GLOBE. Academy of Management Perspectives, v. 20, n. 1, p. 67-90, 2006.

KARL, Katherine A.; SUTTON, Cynthia L. Job values in today's workforce: a comparison of public and private sector employees. Public Personnel Management, v. 27, n. 4, p. 515-527, 1998.

KIM, Sangmook. Gender differences in the job satisfaction of public employees: a study of Seoul metropolitan government, Korea. Sex Roles, v. 52, n. 9-10, p. 667-681, 2005.

LEE, Tae H. et al. Understanding voluntary turnover: path-specific job satisfaction effects and the importance of unsolicited job offers. Academy of Management Journal, v. 51, n. 4. p. 651-671, 2008.

LOCKE, Edwin A. The nature and causes of job satisfaction. In: DUNETTE, M. D. Handbook of industrial and organizational psychology. Chicago: Rand McNaly, 1976. p. 1297-1349.

MALHOTRA, Naresh K. Marketing research: an applied orientation. 4. ed. Nova Jersey: Prentice Hall, 2004.

MALHOTRA, Naresh K.; KIM, Sung S.; PATIL, Ashutosh. Common method variance in IS research: a comparison of alternative approaches and a reanalysis of past research. Management Science, v. 52, n. 12, p. 1865-1883, 2006.

MATIAS-PEREIRA, José. Administração pública comparada: uma avaliação das reformas administrativas do Brasil, EUA e União Europeia. Rev. Adm. Pública, Rio de Janeiro, v. 42, n. 1, p. 61-82, jan./fev. 2008.

MOTTA, Fernando C. P. Cultura e organizações no Brasil. São Paulo: EAESP-FGV, 1996.

PERRY, James L.; RAINEY, Hal G. The public-private distinction in organizational theory: a critique and research strategy. Academy of Management Review, v. 13, n. 2, p. 182-201, 1988.

PERRY, James L.; WISE, Lois R. The motivational bases of public service. Public Administration Review, v. 50, n. 3, p. 367-373, 1990. 
PROENCA, E. Jose. A model of antecedents, mediators and moderators of satisfaction and turnover among service workers. International Journal of Business and Social Science, v. 3, n. 5, p. 37-45, 2012.

RAINEY, Hal G. Public agencies and private firms: incentive structures, goals, and individual roles. Administration \& Society, v. 15, n. 2, p. 207-242, 1983.

RAINEY, Hal G.; BOZEMAN, Barry. Comparing public and private organizations: empirical research and the power of a priori. Journal of Public Administration Research and Theory, v. 10, n. 2, p. 447-470, 2000.

RODRIGUES, Paulo R. A. A cultura empresarial brasileira e a Companhia Vale do Rio Doce. Rev. Adm. Pública, Rio de Janeiro, v. 35, n. 6, p. 23-32, 2002.

SPECTOR, Paul E. Method variance in organizational research truth or urban legend? Organizational Research Methods, v. 9, n. 2, p. 221-232, 2006.

VALOR ECONÔMICO. 1000 maiores empresas e as campeãs em 25 setores e 5 regiões. Valor 1000, v. 10, n. 10, p. 1-454, 2010.

WALTON, Richard E. Quality of working life: what is it? Sloan Management Review, v. 15, n. 1, p. 11-21, 1973.

WANG, Yau-De; YANG, Chyan; WANG, Kuei-Ying. Comparing public and private employees' job satisfaction and turnover. Public Personnel Management, v. 41, n. 3, p. 557-573, 2012.

WERTHER, William B.; DAVIS, Kingsley. Administração de pessoal e recursos humanos. São Paulo: McGraw-Hill do Brasil, 1983.

WESTLEY, William A. Problems and solutions in the quality of working life. Human Relations, v. 32, n. 2, p. 113-123, 1979.

YÜCEL, İlhami. Examining the relationships among job satisfaction, organizational commitment, and turnover intention: an empirical study. International Journal of Business \& Management, v. 20, n. 7, p. 44-58, 2012.

ZHOU, Kevin. Z. et al. Market orientation, job satisfaction, product quality, and firm performance: evidence from China. Strategic Management Journal, v. 29, n. 9, p. 985-1000, 2008.

ZIMMERMAN, Donald W. Invalidation of parametric and nonparametric statistical tests by current violation of two assumptions. The Journal of Experimental Education, v. 67, n. 1, p. 55-68, 1998.

Renata Borges received her $\mathrm{PhD}$ in Business Administration from Southern Illinois University. Assistant professor in the Management Department at Universidade Federal de Minas Gerais (UFMG). E-mail: renatasg@face.ufmg.br. 